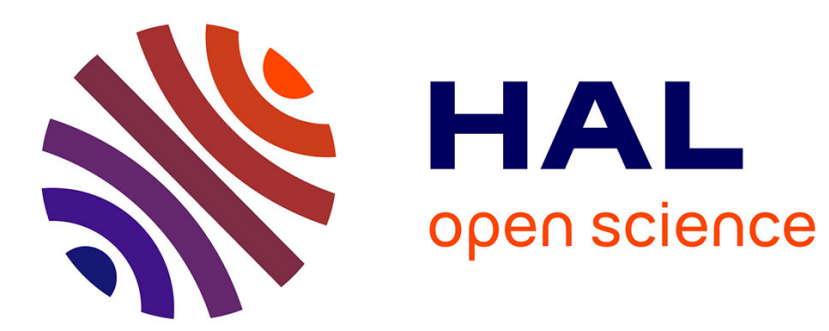

\title{
Serving the general interest with public enterprises - new forms of governance and trends in ownership Philippe Bance, Obermann Gabriel
}

\section{To cite this version:}

Philippe Bance, Obermann Gabriel. Serving the general interest with public enterprises - new forms of governance and trends in ownership. Annals of Public and Cooperative Economics, 2015, 10.1111/apce.12101 . halshs-01965127

\section{HAL Id: halshs-01965127 https://shs.hal.science/halshs-01965127}

Submitted on 24 Dec 2018

HAL is a multi-disciplinary open access archive for the deposit and dissemination of scientific research documents, whether they are published or not. The documents may come from teaching and research institutions in France or abroad, or from public or private research centers.
L'archive ouverte pluridisciplinaire HAL, est destinée au dépôt et à la diffusion de documents scientifiques de niveau recherche, publiés ou non, émanant des établissements d'enseignement et de recherche français ou étrangers, des laboratoires publics ou privés. 


\section{Serving the general interest with public enterprises}

\section{- new forms of governance and trends in ownership}

By

Philippe Bance, Normandie Université (U. Rouen)

And

Gabriel Obermann, WU Vienna University of Economics and Business

After the 1980s, due to different reasons massive privatizations of public owned enterprises occurred worldwide. The form of organization of the public enterprise seemed characterized by a sustainable and hardly reversible damage of reputation. The European Union had also largely participated to the global privatization process: $45 \%$ of privatized assets around the world from 1988 to 2008 were European (Privatization Barometer; OECD, 2011), from countries of Central and Eastern Europe, but also from Western Europe.

Yet the crisis of 2008 brought a scathing refutation to supporters of privatization and deregulation ideas. In fact, in many countries nationalizations have played a buffer role, as an indispensable remedy to alleviate the serious economic and social consequences of the crisis. This reversal occurred in liberal countries also, especially in Anglo Saxon countries, despite the fact that they are in general reluctant to proactive public interventions. Obviously, it was necessary to rescue ailing firms and to maintain production facilities facing the risk of cessation of activity. It was also the way to provide States with proper instruments to effectively conduct strategic economic and social policies. In addition, local authorities have newly brought some of their public services back under municipal control in order to better influence the public mission and policy of these enterprises (so called "re-municipalisation").

After several decades of neglect in academic discussion public enterprises are recently coming back as an important research topic. Recent contributions take into account new developments in theory and refer to practical experience and new empirical evidence from all over the world. 
A first special issue of the Annals of public and cooperative economy, has treated of the future of public enterprises (Florio and Fecher, 2011). ${ }^{1}$ In 2012 the International Scientific Commission (ISC) "Public Services/Public Enterprises" of CIRIEC launched a call for papers on the same topic ${ }^{2}$ and organized a series of workshops in which various theoretical and empirical issues were presented and discussed with researchers and practitioners. Up to now most of the results of this research program were published in journals and books. The International Review of Applied Economics (2013, Volume 27, Issue 2) and the Journal of Economic Policy Reform (2014, Volume 17, Issue 3), have each recently published a special issue on public enterprises with papers selected from this international scientific program. At the same time, the Scientific Commission "Public Economics" of CIRIEC France published a book, edited by Philippe Bance, about internalisation of general interest missions by public organisations (2015). A book with fifteen case studies of contemporary public enterprises, edited by Luc Bernier (2015), has been published recently. In February 2015 an overview of important results of CIRIEC's research was presented at an International Conference at the Ministry for the Economy and Finance in Paris.

This special issue of the Annals of Public and Cooperative Economics concludes this research initiative of CIRIEC's International Scientific Commission "Public services/Public enterprises" and brings together nine selected papers from works carried out within the framework of the program. These contributions shed light on two central questions concerning the possible renewal of public enterprises: why consider that the role of public enterprises can be important for serving the general interest in the future, and how design in such a perspective new forms of public governance? The considerations that are offered to these questions presented in this volume in four groups of contributions.

\section{Public and private enterprises compared}

The first group deals with the question of the effectiveness of public enterprises compared with private enterprises. A renewal of public enterprises is indeed

\footnotetext{
${ }^{1}$ A short overview of CIRIEC's research topics and activities on public enterprises in the last 25 years can be found in Bognetti and Obermann (2008).

2 The Future of Public Enterprise, Mission, Performance and Governance: Learning from Success and Failure. Steering Committee: Gabriel Obermann (president in 2012 of the ISC), Philippe Bance, Luc Bernier, Massimo Florio.
} 
legitimate if this type of organization appears (more) effective in serving the general interest, and particularly if it is not associated with intrinsic inefficiencies usually denounced by property rights theory.

A lot of researchers consider that the literature of the past decades has often highlighted a greater efficiency of private enterprises vis-à-vis public enterprises. The paper by Mühlenkamp, "From State to Market Revisited: Empirical Evidence on the Efficiency of Public (and Privately-owned) Enterprises", addresses this important issue. It shows that the often claimed superiority of private enterprises as a rule is not justified and that there is need of a comprehensive and accurate reasoning. Several arguments put forward permit to understand why the approaches and results frequently developed in public-private comparisons are misleading. Many analyses suffer by a sample selection bias: enterprises selected are often chosen in a way to obtain the desired conclusion. Besides that, in many comparisons of public versus private enterprises profitability is not an adequate criteria and no valid argument to prove superior performance of private companies.

The obligation of enterprises to serve the general interest has often negative consequences for their profitability. It is therefore necessary to refer to other criteria, like effects of firms on welfare or on macroeconomic policies, for appreciating the effectiveness of firms. Redistributive effects of public enterprises must be also balanced against pure efficiency. Furthermore, under conditions of market failures, it is recommended to maintain appropriate levels of competition between different institutional arrangements for delivering public services.

The second paper, "Public enterprises in the market for corporate control: Recent worldwide evidence", by Clo et al., focusses more particularly on a comparison of effectiveness between public and private enterprises' strategies of mergers and acquisitions from 2004 to 2012, using data bases permitting such an in depth analysis for the first time. The mains results are a refutation of the widely held arguments which postulate a supposed superiority of private firms. In fact, public acquirers have larger assets, number of employees, and turnover than private firms. They have also a better financial performance on the criteria of ROS (Return on Sale) and of EBIT (Earnings before Interest and Taxes) than their private and public targets. Like private firms, state owned enterprises acquire less efficient (in the conventional meaning of the financial literature focusing on profitability) private and 
public firms. Furthermore, in deals in recent years, some publicly-owned enterprises are still active players and are well-performing and capitalized. Moreover, it appears that active state owned enterprises are on average at least as profitable as their private counterparts in the same industries.

\section{Relevance of public control}

The second group of papers highlights weaknesses and strengths of public enterprises depending on the design and effectiveness of public control. Two case studies give insight in very special constellations of public service provision and control in different national and sectorial contexts.

The paper by Bird, "The Muddling Crown: VIA Rail and the Federal Government", provides an illustration of difficulties resulting from a lack of precise and clear objectives prescribed by the owner of a public enterprise. Indeed, the progressive decline of the Canadian Railways enterprise Via Rail can be measured by its falling passenger number. This decline of a public enterprise in the long run was not in fact ineluctable: its principal American counterpart Amtrak demonstrated during the last years an expansion of its activities, and other Canadian Railways enterprises of the sector were also modernized and operated satisfactorily. The paper specifies the reasons for this predicament of the public railway company: the absence of initiative by federal authorities to introduce necessary changes permitting a positive development of the enterprise. The responsible public authorities did not take into account the need of reform, did not define a clear public mission to Via Rail, and keep the enterprise in a state of stasis and largely at the behest of influential actors with individual interests. This situation could encourage privatization attempts in the future if modernisation is not decided quickly.

The constellation of political control in the water and sewage sector in Germany is very different from that in VIA Rail. The paper by Schaefer and Warm, "Financial instruments and socially effective tariff calculations for public services - Using the example of the German water sector", deals with questions of the provision of public services by public and private enterprises in a comparative view. It focusses on socially effective calculation of tariffs for these services, shows in some detail the relevance of different treatment of public and private enterprises with regard to 
taxation, challenges for monitoring and controlling of enterprises, and discusses unsolved issues of calculation of social tariffs. The paper concludes that, in the sectorial context of decentralisation there are arguments in favour of remunicipalisation: the protection of influence and control by the municipalities, a better surveillance of water sector, and control of the risk of too high pricing. The public enterprises can be, for the future of the pricing in this sector, serve as a means to exercise a consistent surveillance, a fair treatment of tax law and a better regulation of calculations.

\section{Modes of governance}

The third group of papers deals with current or desirable changes for public enterprises' mode of governance. Three papers are focused on specific problems and opportunities of governance of public enterprises.

The paper by Rentsch and Finger, titled "Yes, no, maybe: the ambiguous relationships between State-owned enterprises and State", examines the effects of recent institutional changes, namely the introduction of sector-specific regulators during the last decades, focussing more particularly on three countries: France, Germany and Switzerland. The authors show how and why the originally relationships between public enterprises and their States have become ambiguous with these transformations. On one hand, public enterprises want to emancipate from their State but pursue non-market strategies and seek its protection. On the other hand, the States keep interested in the control of strategic firms, and role conflicts exist in their behaviour as owner and regulator of public enterprises. This constellation depends thus on the context but shows situations where States are not capable of adopting a coherent position vis-à-vis their enterprises.

Greiling and Grüb, in their paper "Towards citizen accountability of local public enterprises" focus for their part on the question of accountability of public enterprises in Austria and Germany. They argue that accountability expectations and obligations are higher for public enterprises than for private, due to public ownership and specific public mission objectives. But the hitherto presented efforts of sustainability reporting with respect to citizen accountability are insufficient, far from being comprehensive, particularly in the social dimension, and focus too much on the financial dimension. 
Nevertheless, control mechanism for narrowing the gap between the citizens as principals and the public enterprises and politicians as agents could be introduced, combining public value reporting with other methods such as cost-benefit-analysis. An analysis of the SROI (Social Return on Investment), with the public value report, would also be an improvement, to show it performs better than cost-benefit-analyses with respect to stakeholder orientation. To define what the real public value means for the citizens, it would be essential to integrate citizens into the specification of the reporting requirements.

The paper by Ahmed-Zaïd and Bance, "Public governances and public enterprises in economies of rent" concerns more specifically countries benefitting petroleum and gas' resources. These countries are frequently affected by a perverse phenomenon of resources' dilapidation and bad economic performances, called "resource curse". The analysis examines new modes of governance to fight against dilapidation of resources and bad incentives for public enterprises and in governance mechanisms. The emergence of strategist States is shown as an essential change to support industrial development policies and make public enterprises more efficient to serve missions of general interest. Transparent public accounts, objective and critical approaches on impact of investments, a dynamic of co-construction of public policies by participatory assessments, a collective learning on reforms, new forms of incentives are measures considered as essential reforms to change agents' behaviours and reduce the culture of rent seeking.

\section{Future roles for public enterprises}

The last group of contributions deals with new roles and functions for public enterprises in the future.

The paper by Bauby and Similie, "Conditions for the emergence and institutionalization of 'European Public Enterprises'”, describes possibilities and opportunities of the creation of public enterprises by the European institutions themselves. It concerns more explicitly the capacity to utilize public enterprises as an instrument of public action in the European Union and to transfer them from a national to a transnational level. European agencies, funding institutions and European joint undertakings like Galileo already exist; but there is no specified legal 
form of an EU public enterprise, i.e. an enterprise under direct control of European institutions (e.g. the Commission). The paper argues from a legal perspective that in principle there is no obstacle to create such public enterprises in order to contribute to European services of general economic interest. It would be necessary to define the legal status of these enterprises controlled by the Commission, be precise clearly about their rules, objectives and missions as well as the modes of organisation of such entities. In other terms, a real political will is needed and require putting in place a specific branch of EU law.

Another possible future perspective of public enterprises is to extend their mission to contribute to the fight against the global greenhouse effect. The paper by Bance, "Public enterprises and production of global public goods: the effectiveness of internalising public missions in relation to climate issues", explores this possibility in a context marked by radical uncertainties on technological changes. It shows the specific behaviour of public enterprises, their ability to free themselves from a fast return on investment could permit to internalize binding public-interest missions for applying a proactive policy to prevent the greenhouse effect. The paper highlights the crucial need to develop new technologies and radical innovations, especially to make the production of global public goods with high environmental impact more efficient, to overcome the lack of private investment in activities where technological uncertainty is deep-rooted and return on investment riskier. In this context, public enterprises could actively contribute to the implementation of such environmental policy in the areas of energy and transport, and be a tool for international cooperative strategies.

In conclusion, the contributions in this special issue show that the question of resurgence of public enterprises leads to new and in-depth discussions about the strengths, weaknesses and opportunities of these organizations in the economy of today and tomorrow. In the long run the persistence of public enterprises depends on their ability to respond to new challenges, to implement effective governance modes, and internalize efficiently general interest missions. The future role of public enterprises will also depend on the ability to meet social expectations and to convince the public authorities that they can be important tools for promoting economic policies and sustainable development. Obviously, a vast field of research is 
open. In order to contribute to these challenges CIRIEC's International Scientific Commission "Public Enterprises/Public Services", presentliy presided by M. Florio, has continued its research with a new program on the role and significance of major public enterprises in countries all over the world.

Bance P. (dir.), 2015, L'internalisation des missions d'intérêt général par les organisations publiques, Réalités d'aujourd'hui et perspectives, Commission scientifique du CIRIEC France, PURH.

Bernier L. (ed.), 2015, Public Enterprises Today: Missions, Performance, Governance. Lessons from Fifteen Cases Studies, Peter Lang.

Bognetti G. and Obermann G., 2008, Liberalization and Privatization of Public Utilities: Origins of the Debate, Current Issues, and Challenges for the Future, Annals of public and cooperative economics vol. 73, 3-4.

Florio M. and Fecher F. (eds.), 2011, Annals of public and cooperative economics, The future of public enterprises: contribution to a new discourse, vol. 82, special issue, 4.

OECD, 2011, The size and composition of the SOE sector in OECD countries, OECD Corporate Governance Working Papers, No.5, by H. Christiansen, http://www.oecd.org/dataoecd/55/42/48512721.pdf.

Privatization Barometer, reports, 1988-2014 www.privatizationbarometer.net. 